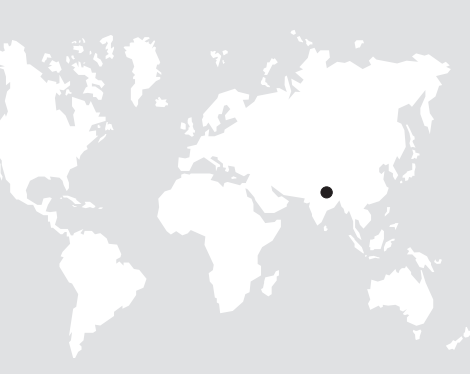

Water remains one of the major issues in the Middle Mountains of the Hindu Kush-Himalayas. This most populated region of Nepal depends mainly on rainwater supply, which is highly variable: around $85 \%$ of annual rainfall is expected during the monsoon, which lasts about 4 months from June to September. During this season, the major concern in many parts of the region is flooding and surface erosion due to too much water. During the remaining 8 months, water shortage for domestic and agricultural use is a persistent problem.

This article discusses water availability considerations in 2 watersheds in the Middle Mountains of Nepal. A survey of the water need and supply situation was carried out in both watersheds. The survey revealed the most needy regions within the watersheds and local residents' major concerns. Their main apprehension is water availability for both agricultural and domestic purposes, and increasingly, water quality concerns are mentioned in villages. A comparison between the 2 watersheds is particularly interesting because of their location in relation to Kathmandu, a major market opportunity for vegetable farmers. This study concludes that with the increasing pressure on available water resources, new forms of water resources management at watershed scale have to be introduced. They must be based on the social background of the area and on the technical possibilities in terms of both locally available knowledge and scientific information.

Keywords: Water availability; water quality; Middle Mountains; Nepal.

Peer reviewed: October 2002. Accepted: November 2002.

\section{The need for a holistic understanding}

Worldwide, water availability will be a key issue in the 21 st century. Per capita water availability is projected to fall from 6600 to $4800 \mathrm{~m}^{3}$ between 2000 and 2025 because of uneven distribution of water resources. However, most of the world's population will have below $1700 \mathrm{~m}^{3}$ per capita (Cosgrove and Rijsberman 2000). Mountains, in particular, are of great importance because more than half of humanity relies on freshwater that originates from mountains (Liniger et al 1998; Viviroli 2001). The rising demand for water from growing populations, climate change affecting water sup- plies, and increased uncertainty in relation to natural hazards (eg, increased occurrence of landslides, glacial lake outburst floods) are some of the reasons for future concern (Kundzewicz et al 2001). In the context of the Hindu Kush-Himalayan (HKH) region with its pronounced monsoonal climate, the following dual concern can be demonstrated by the current status of water-related issues:

- Flooding, surface erosion, and landslides triggered by intense rainfall events in the monsoon highlight the role of water in land degradation. The problem in this context is too much water.

- Drying up of rivers, insufficient water available for irrigation, and long queues at public water sources reveal that water is a scarce resource. The water supply from public sources is often inadequate because of scarce rainfall and low recharge of shallow aquifers during the dry season, which can last up to 8 months per year. The problem in this context is too little water.

In addition, water quality deterioration is increasingly becoming a concern in many parts of the $\mathrm{HKH}$ region. In this respect, agrochemical pollution causing eutrophication and untreated waste are the main issues in Asia (Kraemer et al 2001). The present condition of the Bagmati watershed, particularly around the city of Kathmandu, is a good example. Most of the wastewater from Kathmandu Valley is diverted into the waters of the Bagmati, leading to dangerous levels of pollution (DHM 1996).

Whereas in urban areas, point-source pollution and untreated stormflow are the major concerns, in the rural areas of Nepal, water quality deterioration is rather believed to be the result of non-point-source pollution by human waste and intensive agriculture with high mineral fertilizer and pesticide inputs. In certain locations, increasing numbers of livestock for dairy farming are adding to the non-point-source pollution problem. Because water is a scarce commodity in large parts of the Middle Mountains in the HKH region and Nepal, particularly during winter (dry season), people are forced to drink whatever water is available. During the monsoon (rainy season), the problem of feces and other pollutants being washed into the river system and water sources adds to the health risk.

A holistic understanding of water in rural watersheds of the Middle Mountains of the HKH region is one of the objectives of the People and Resource Dynamics of Mountain Watersheds in the Hindu Kush-Himalayas Project (PARDYP). This project, which is a regional research-for-development project in the field of watershed and natural resources management implemented by the International Centre for Integrat- 
TABLE 1 Catchment characteristics of JKW and YKW (Source: PARDYP).

\begin{tabular}{|c|c|c|}
\hline Description & JKW & YKW \\
\hline Catchment area in $\mathbf{k m}^{2}$ & 111.4 & 53.4 \\
\hline Altitudinal range in $\mathrm{m}$ & $800-2200$ & 990-3030 \\
\hline Physiography & $\begin{array}{l}\text { Flat valley bottom of alluvial origin; short } \\
\text { and steep slopes on northern and } \\
\text { southern margins }\end{array}$ & $\begin{array}{l}\text { Bowl-shaped valley with limited flat } \\
\text { portions }\end{array}$ \\
\hline Dominant land use & $\begin{array}{l}\text { Irrigated agricultural land in the valley } \\
\text { bottom, rainfed agricultural land, and } \\
\text { forestland on the slopes }\end{array}$ & $\begin{array}{l}\text { Rainfed agricultural land and forest with } \\
\text { irrigated land along the river courses and } \\
\text { the lower parts }\end{array}$ \\
\hline General aspect & $\begin{array}{l}\text { Southeast (main valley extending from } \\
\text { northwest to southeast) }\end{array}$ & $\begin{array}{l}\text { Southwest (main valley extending from } \\
\text { northeast to southwest) }\end{array}$ \\
\hline $\begin{array}{l}\text { Annual rainfall in } \mathrm{mm} \text { at main meteor- } \\
\text { ological stations (period) }\end{array}$ & $\begin{array}{l}\text { 1167-1418 at Tamaghat, } 865 \mathrm{~m} \\
(1998-2000)\end{array}$ & $\begin{array}{l}2018-2469 \text { at Bagar, } 1690 \mathrm{~m} \\
(1998-2000)\end{array}$ \\
\hline $\begin{array}{l}\text { Spatial rainfall variability in } \mathrm{mm} \\
\text { (period) }\end{array}$ & $\begin{array}{l}1100-1700 \text { between } 830 \text { and } 1700 \text { m } \\
(1998-2000)\end{array}$ & $\begin{array}{l}\text { 1600-3000 between } 1005 \text { and } 2640 \text { m } \\
(1998-2000)\end{array}$ \\
\hline Market access & Good & Limited \\
\hline $\begin{array}{l}\text { Population density in people } / \mathrm{km}^{2} \\
\text { (year) }\end{array}$ & 437 (1996) & 386 (1996) \\
\hline
\end{tabular}

ed Mountain Development (ICIMOD), focuses on 5 watersheds in China, India, Nepal, and Pakistan. Waterrelated activities include hydrometeorological monitoring, water quality surveys, water management, and soil and water conservation from the biophysical as well as the socioeconomic points of view (Merz et al 2000b).

The aims of this paper are to:

1. Document people's perception of water resources issues in 2 mountain watersheds of Nepal's Middle Mountains.

2. Provide quantitative data on the quality and quantity problem facing the inhabitants.

3. Explain why water shortages are increasing and water quality is deteriorating.

4. Contribute to the awareness of water issues in mountain areas in the context of the International Year of Mountains 2002 and the International Year of Freshwater 2003.

\section{The watersheds}

PARDYP Nepal focuses on the watersheds of Jhikhu Khola (JKW) and Yarsha Khola (YKW). Both are located in the Middle Mountains of Nepal (Figure 1). JKW is situated about $45 \mathrm{~km}$ east of Kathmandu on the Arniko Highway and covers a surface area of $111.4 \mathrm{~km}^{2}$. YKW is located about $190 \mathrm{~km}$ east of Kathmandu on the Lamosangu-Jiri Road in Dholaka District, and has an area of $53.4 \mathrm{~km}^{2}$. Further relevant information on the watersheds is compiled in Table 1 .

\section{Methods and methodology}

PARDYP is applying different methods for assessment and documentation of water-related issues in the 2 watersheds. These include regular monitoring of meteorological and hydrological parameters, a survey of public water sources, water quality analyses in streams and public water sources, and a household survey. The results presented here are mainly derived from the household survey focusing on constraints and issues related to water as perceived by local residents.

The survey was conducted by local enumerators, who were trained by PARDYP in the use of participatory rural appraisal methods and analysis of aerial photographs, using a questionnaire in the Nepali language. A separate questionnaire was used for female and male household heads of the same household. This separation resulted from a rapid rural appraisal exercise, which showed that female household heads are responsible for activities relating to the household and management of animals, whereas the male household heads decide upon management issues relating to water use in irrigation. Sampling was done using a 2-households-per-km² grid in JKW and a stratification approach according to elevation and aspect in YKW (Merz et al 2002). All data were geo-referenced for input into a geographic information system, to enable spatial analysis of the data.

In YKW, a total of 436 persons (about $2 \%$ of the total population) were interviewed from 218 households (218 females and 218 males); in JKW, 356 


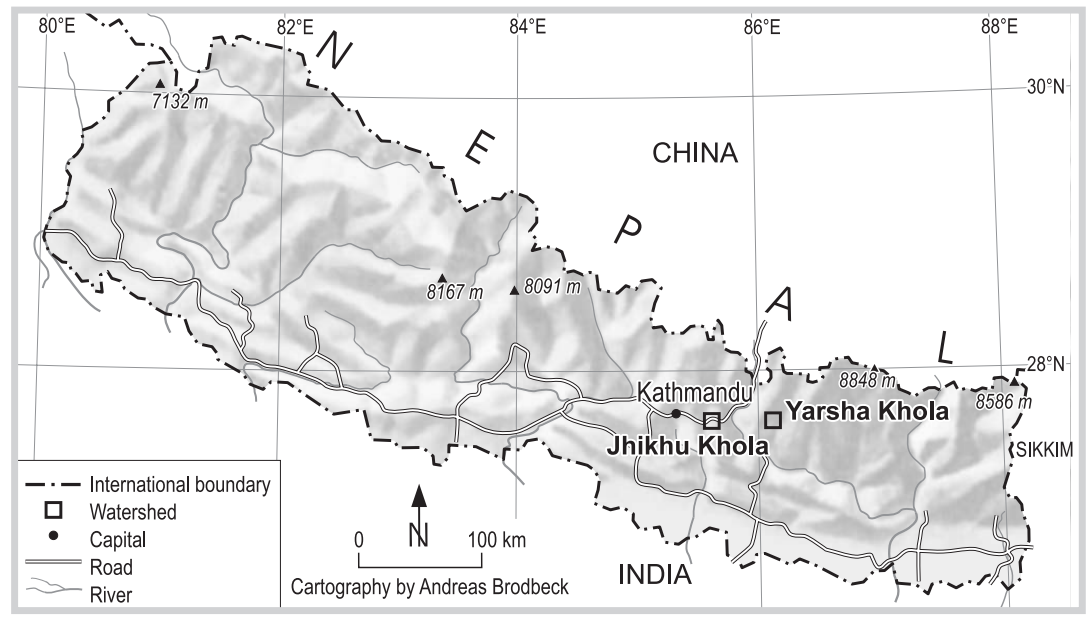

FIGURE 1 Locations of JKW and YKW.

(Map by Alex Hermann)
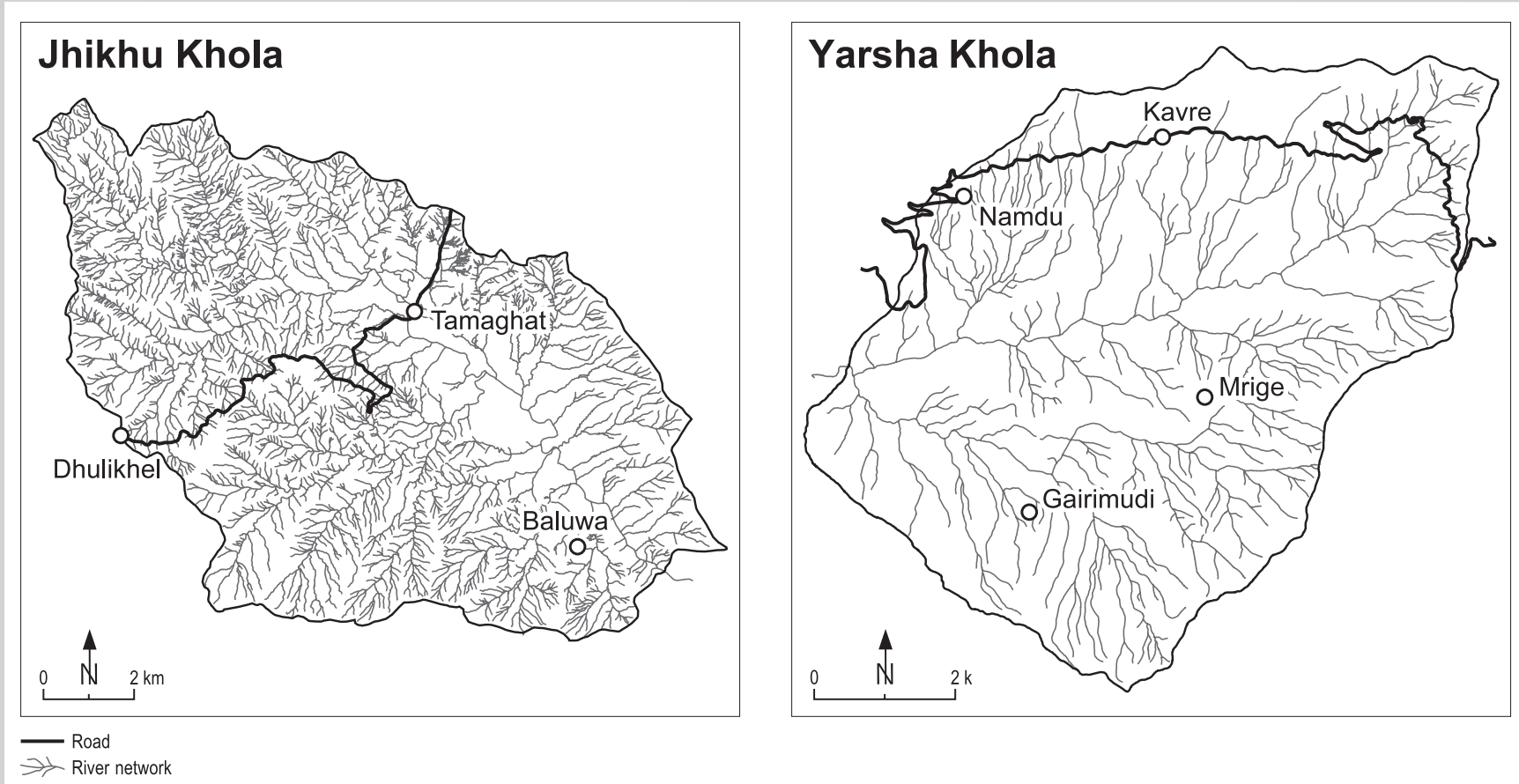

persons (1\%) from 178 households (178 females and 178 males) were surveyed.

\section{Results}

\section{Local perceptions of water-related issues}

Overall, both watersheds are perceived as being dry by their residents. Seventy-five percent of the residents in JKW indicated that their area was dry, whereas 53\% answered the same in YKW. Forty-four percent of respondents in YKW said that they believed their area was wet; the remaining $3 \%$ expressed no opinion. This response is of particular interest when one notes that people along the boundary of YKW perceive their area as being dry, although annual precipitation of about $3000 \mathrm{~mm}$ can be expected.

In both watersheds, water quantity is a major concern (Figure 2). Irrigation water in particular is in short supply. Thirty-three percent of respondents in JKW and $41 \%$ in YKW mentioned that they faced irrigation water shortages. This is closely followed by domestic water shortage, with $27 \%$ of respondents in JKW and $37 \%$ in YKW stating that they have insufficient quantities of domestic water available. 
FIGURE 2 Responses of interviewees to questions on water-related problems in JKW (A) and YKW (B) (JKW, 356 respondents; YKW, 436 respondents; multiple answers were possible).
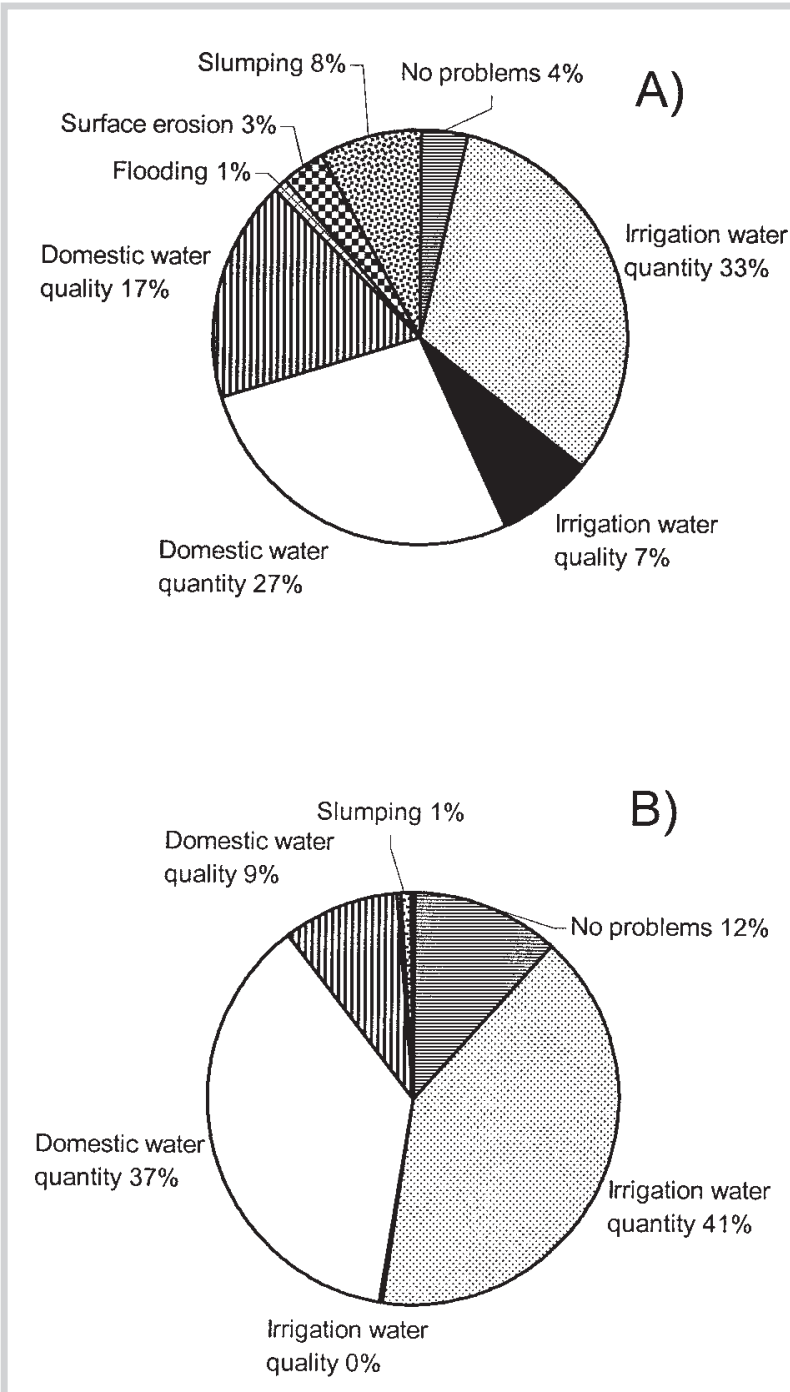

Domestic water quality is increasingly becoming a concern, with $17 \%$ of respondents in JKW and $9 \%$ in YKW stating that they have water quality problems.

An interesting picture emerges when one divides the watersheds into different zones according to elevation and aspect. This division is based on the assumption that water availability changes with increasing altitude because of differences in both rainfall conditions and topographic settings. Aspect influences rainfall input as well as water loss through evapotranspiration.

From Table 2, it is evident that domestic water problems are widespread in JKW. The situation is slightly more problematic on south-facing slopes than on north-facing slopes. In YKW, on the other hand, mainly higher areas face water problems, both on northern and on southern slopes.
In terms of irrigation water, all areas in JKW face water supply constraints, except the area between 1000 and $1500 \mathrm{~m}$ on north-facing slopes. These areas along northern slopes of the watershed have direct access to rivers, with only few diversions further upstream. It is argued that there used to be enough water in the valley when a more traditional farming system existed (less than 2 crops per year). With the introduction of cash crops and a multiple cropping system, the demand on water resources has increased significantly but supply has remained the same per unit area. This has led to inadequate water supply in general, and not only for the new agricultural practices.

In YKW, the areas along the divide face irrigation water constraints because of nonavailability of sources with adequate yield or access to rivers. Areas below 1500 $\mathrm{m}$ are the main irrigation areas of the watershed. Irrigation water shortage in these areas is due to diversion of water by upstream farmers.

From the aforementioned data, it is clear that elevation is not the main reason for water constraints or inadequate water supply. The topographic setting, site conditions according to aspect, and seasonal differences as discussed in Merz et al (2002) are more important. Although the uppermost areas in the watershed along the divide receive the highest rainfall, they are the areas with least access to springs and rivers. In many places, residents of these areas have to walk long distances for their drinking water. In lower areas, water availability may be affected by upstream diversions mainly during the dry season. Intensification of agricultural production has led to increased water demand in irrigated areas and is therefore the main reason for water supply constraints. This is shown by the high percentage of respondents mentioning irrigation water shortage at present (Figure 2) and by the increase in the percentage of such respondents over the last 5 and 25 years (Figure 3 ).

It is interesting to note that-according to responses from participants - too much water during monsoon causing flooding, land degradation, and slumping of terraces is not an issue in the perception of respondents. These factors are often said to be a major problem, especially from an external point of view. Other hazards rarely mentioned by farmers were drought and disputes over water.

In summary, it can be said that in the perception of local residents in watersheds of the Middle Mountains of Nepal, the areas of interest and focus are agricultural water supply and domestic water supply, both in terms of quantity and quality (both will be discussed in more detail below). Land degradation by water and flooding is of concern to those living in downstream communities and to scientists, but receives little attention from local residents in the upper parts of the watersheds. The rea- 
FIGURE 3 Perceptions of changes in irrigation and domestic water supply in JKW and YKW over periods of 25 and 5 years.

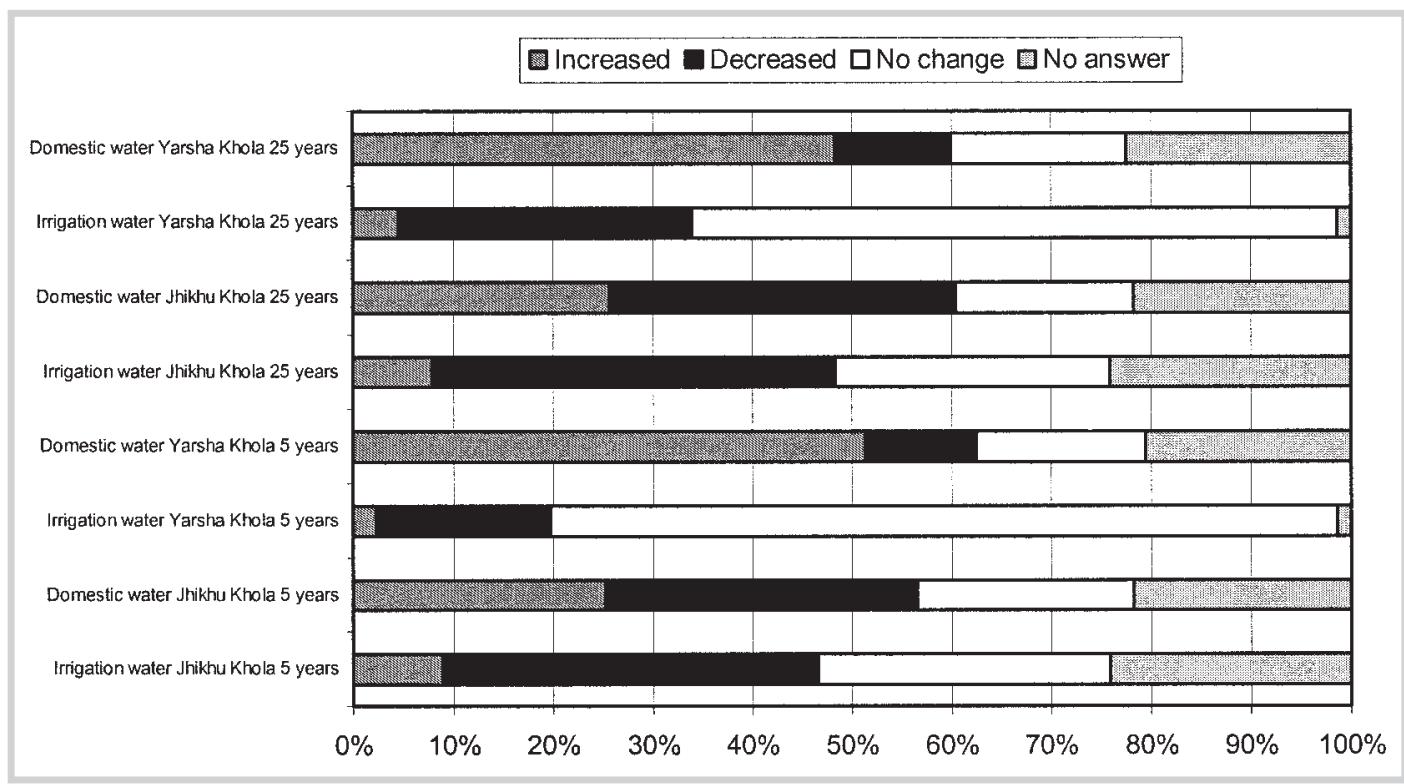

TABLE 2 Water shortage as perceived by respondents, disaggregated according to elevation and aspect. White cells indicate that more than two thirds of the respondents face water shortages. (Source: PARDYP).

\begin{tabular}{|c|c|c|c|c|c|c|c|c|}
\hline & \multicolumn{4}{|c|}{ Irrigation water shortage } & \multicolumn{4}{|c|}{ Domestic water shortage } \\
\hline & $\begin{array}{l}\text { North } \\
\text { (No.) }\end{array}$ & $\begin{array}{c}\text { North } \\
\text { (\%) }\end{array}$ & $\begin{array}{l}\text { South } \\
\text { (No.) }\end{array}$ & $\begin{array}{c}\text { South } \\
\text { (\%) }\end{array}$ & $\begin{array}{l}\text { North } \\
\text { (No.) }\end{array}$ & $\begin{array}{c}\text { North } \\
(\%)\end{array}$ & $\begin{array}{l}\text { South } \\
\text { (No.) }\end{array}$ & $\begin{array}{c}\text { South } \\
\text { (\%) }\end{array}$ \\
\hline \multicolumn{9}{|l|}{ YKW } \\
\hline $1000-1500 \mathrm{~m}$ & 32 & 78 & 33 & 83 & 25 & 63 & 18 & 45 \\
\hline $1500-1900 \mathrm{~m}$ & 31 & 52 & 24 & 60 & 47 & 78 & 19 & 48 \\
\hline $1900-2200 \mathrm{~m}$ & 21 & 53 & 53 & 63 & 21 & 53 & 43 & 54 \\
\hline$\geq 2200 \mathrm{~m}$ & 14 & 88 & 15 & 75 & 14 & 88 & 14 & 70 \\
\hline \multicolumn{9}{|l|}{ JKW } \\
\hline$\leq 1000 \mathrm{~m}$ & 19 & 100 & 33 & 73 & 16 & 76 & 35 & 81 \\
\hline $1000-1500 \mathrm{~m}$ & 37 & 41 & 27 & 66 & 44 & 88 & 37 & 88 \\
\hline $1500-1900 \mathrm{~m}$ & 8 & 67 & 8 & 89 & 9 & 75 & 8 & 89 \\
\hline
\end{tabular}

son for this is that upstream residents are hardly affected; moreover, little can be done about such natural calamities.

\section{Agricultural water supply}

As shown above, adequate water supply for irrigation is the main constraint in both watersheds, and water shortage is mainly confined to the dry winter and premonsoon months (ie, November to May/June [Merz et al 2000a]). The main cropping patterns that use irrigation are rice-potato-maize, rice-wheat-different crops, and rice-wheat in JKW and rice-wheat in YKW. Therefore, the perceived water shortage pattern affects crops like potato, wheat, and different cash crops in JKW and wheat in YKW. No problems are envisaged for the rice crops grown during the monsoon in both watersheds.
On rainfed agricultural land, farmers usually follow a maize-wheat or maize-different crops (JKW) and maize-millet (YKW) rotation. Crops are affected by dry conditions mainly outside the monsoon season or during the transplanting time of monsoon crops. With the increasing intensity of agricultural production, the use of high-yielding varieties, and triple to quadruple crop rotations, irrigation water supply has shown a decreasing trend in JKW in the last few years, according to respondents. Thirty-eight percent of respondents indicated a decreasing trend, with $29 \%$ indicating no change; $24 \%$ did not provide an answer, and $9 \%$ indicated an increase in water availability (Figure 3). In YKW, where intensification has only taken place to a limited degree, most respondents did not indicate any change $(79 \%)$. However, $17 \%$ of respondents indicated a decreasing trend, $2 \%$ an increasing trend, and $1 \%$ did not answer. 
FIGURE 4 Phosphate levels in milligrams per liter in samples from the rivers in JKW in 4 different seasons. Land-use types and sampling sites are shown on the map. (Map by Alex Hermann)

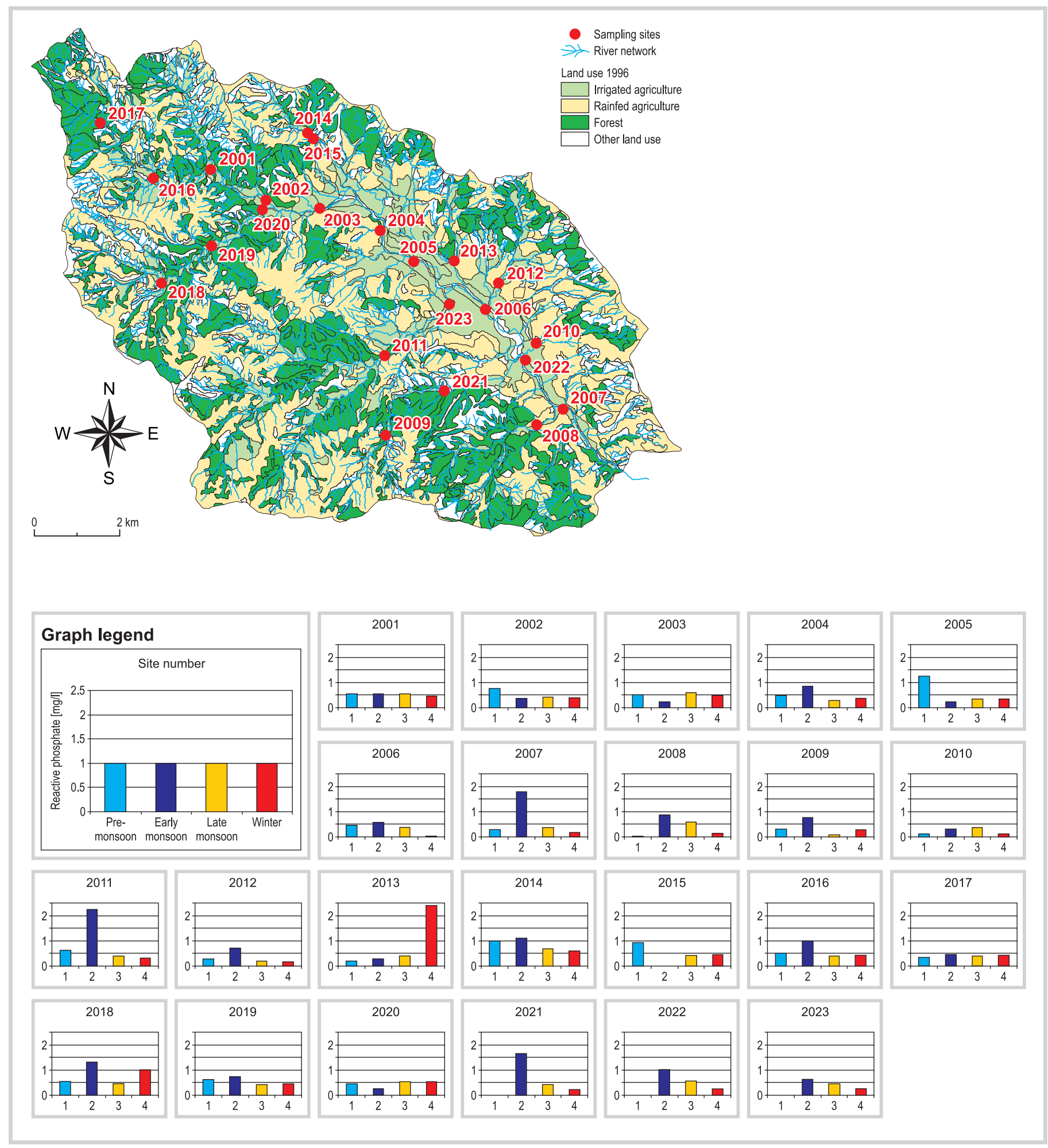


There is no evidence that rainfall rates have decreased over the last 20 years, so this can be discarded as the reason for decreasing water availability (Merz et al 2002). Increasing cropping intensity has been documented by Shrestha and Brown (1995), who have shown that mean cropping intensity in JKW changed from 1.3 to 2.5 between 1980 and 1994, with up to 4 crops per year on prime agricultural land. According to Schreier and Shah (2000), soil fertility is decreasing because of this intensification, and farmers try to compensate this loss in soil fertility by applying high doses of mineral fertilizer. Farmers in JKW apply up to $400 \mathrm{~kg}$ urea per hectare $(46 \%$ nitrogen [Pandey and Joshy $2000]), 800 \mathrm{~kg}$ diammonium phosphate (18\% nitrogen, $46 \%$ phosphorus), and $800 \mathrm{~kg}$ complex fertilizer $(20 \%$ nitrogen, $20 \%$ phosphorus) to their potato crops. Other crops are supplied with about $200 \mathrm{~kg} / \mathrm{ha}$ of the different fertilizers.

High fertilizer application rates have led to a change in the soil nutrient balance. Phosphorus is now mostly available in surplus in the soil, whereas potassium is in short supply in most cases (VanWestarp 2002).

Phosphate is lacking in all bedrock in the area, and soils are inherently low in phosphate content. The farmers, therefore, add high doses of fertilizers to their intensively used fields. Much of this applied fertilizer is washed into the river system of the watershed as shown by the elevated phosphate levels at selected sites in JKW, mainly during the monsoon but also during the premonsoon season in the upper areas (eg, sites 2002, 2005, 2015, and 2016 [Figure 4]). During this time, DAP fertilizer is applied to the potato crop in these upper areas.

In YKW, the amount of fertilizer is generally limited. The average dosage per hectare of crop generally does not exceed 150-200 kg urea. The potato crop on rainfed land is an exception, for which an average of 20 farmers apply 400-500 kg urea per hectare.

Heavy doses of fertilizer and intensive use of agricultural land have had an impact on water quality in the watershed, as shown by the water quality survey of JKW. The main pollutants are microbes, phosphates, and nitrates. Harmful fecal coliform mainly come from human and animal waste. Phosphate and nitrate pollution is mainly believed to originate from agricultural practices (fertilizer) (Figure 4), and eutrophication can now be observed in many lowland sections of JKW. Detailed investigations of this issue are planned.

Increasing intensification may further deplete available water resources under the current management practices. In addition, the state of the environment may worsen because of deteriorating water quality.

\section{Domestic water supply}

Irrigation water constraints are matched by inadequate supply of water for domestic purposes. Issues in this

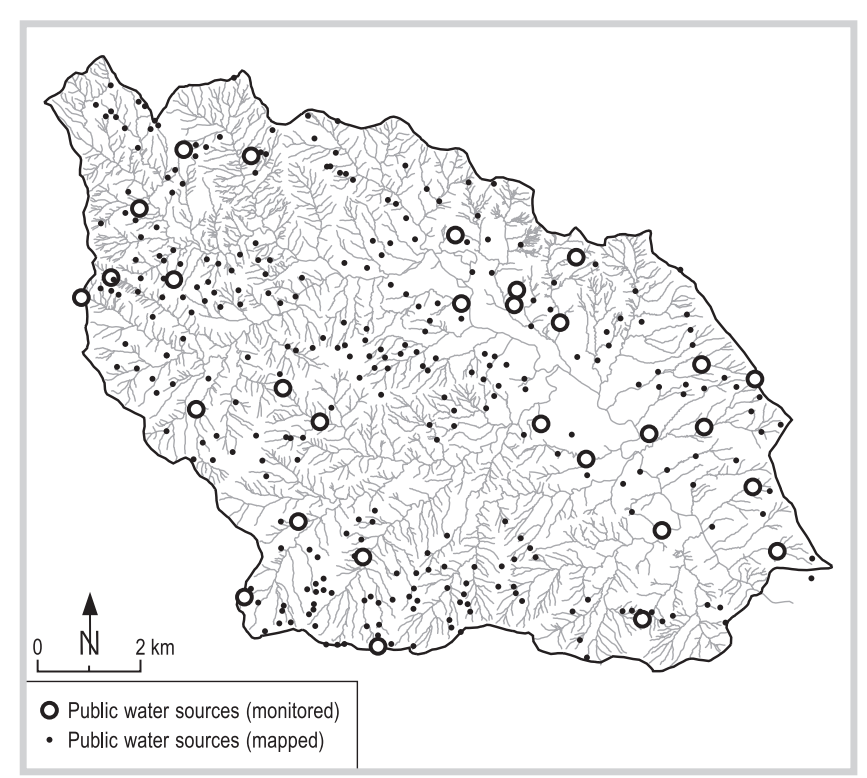

FIGURE 5 Public water sources monitored and mapped in JKW. (Map by Alex Hermann)

respect are the water shortage during the dry season from October to May/June and sediment contamination of public water sources during monsoon. On average, a household uses $160 \mathrm{l} / \mathrm{d}$ in JKW and $122 \mathrm{l} / \mathrm{d}$ in YKW. This equals an amount of $21.1 \mathrm{l} / \mathrm{d}$ per person in YKW and $23.2 \mathrm{l} / \mathrm{d}$ per person in JKW, taking into consideration the average household size of 5.8 persons in YKW and 6.8 in JKW. For rural water supply schemes in Nepal, 45 l/d per person is recommended. For assessment of the current public water supply, a survey of all public water sources was conducted in the 2 watersheds.

During the survey, more than 400 public water sources were identified in JKW. Out of these 400 sources, only 322 were documented on the basis of relevance to local residents. All documented water sources are presented in Figure 5.

The known public water sources in JKW are spring boxes (kuwas), taps, rivers, wells, and springs. The yield, measured toward the end of the monsoon in September 1999 , varies widely from 0.01 to $4.5 \mathrm{l} / \mathrm{s}$. The combined yield of all 322 sources was $58.3 \mathrm{l} / \mathrm{s}$. Most of the sources $(89 \%)$ are community-owned. Only $5 \%$ were government-managed, and $6 \%$ were in private hands. Privatization of the sources is becoming a common issue. More and more people rely on their privately owned water sources, such as dug wells and polythene pipes. The number of households depending on a single source has a considerable effect on supply. The maximum number of households depending on a single source was 290. On average, 18 households depended on a single water source. 
A similar survey was conducted in YKW; 215 public water sources were mapped. Their yield ranged from 0.001 to $3.7 \mathrm{l} / \mathrm{s}$, with a combined yield of $37.7 \mathrm{l} / \mathrm{s}$ in May 2000 (note that this survey was conducted toward the end of the dry season; no direct comparison is therefore possible with the results from JKW).

Water quality investigations of public water sources in JKW confirm the findings from the river sites in this watershed. Thus, $\mathrm{pH}$ values, dissolved oxygen, and turbidity are higher than recommended in certain samples, but the main reasons for concern are microbiological contaminants and phosphate.

Fecal coliform is present in most sampled water sources. The concentrations are usually orders of magnitude above recommended values. In general, fecal coliform content in the samples is higher during monsoon than during premonsoon. The lowest concentrations are measured in postmonsoon and winter (October-February). This is believed to be the result of increased interaction between surface water and shallow groundwater, not to mention the influence of pollution around the sources, which is washed into them. Surface water is usually more contaminated. This was also shown in the case of river water quality monitoring.

Phosphate concentration is of major concern. In most of the sources, phosphate concentration exceeds the limit of $0.4 \mathrm{mg} / \mathrm{l}$ mentioned in guidelines set by the European Union. This is mainly attributable to human activities in and around public water sources. In many cases, washing and bathing around the sources are an integral part of life. Leaching of agricultural contaminants (eg, from DAP fertilizer) into the groundwater increases phosphate levels in the water. Both the origin and consequences of elevated phosphate levels are under closer investigation, and conclusive answers are expected at a later stage. At this point, it has to be mentioned that phosphate does not have a direct impact on human health but may increase organic pollution.

Microbiological contamination has a significant impact on the health of people in the watershed, as shown by a survey of health posts in JKW. According to health officials, $25 \%$ of patients visiting the 9 health units and health and subhealth posts suffer from waterrelated diseases. Most patients suffer from diarrhea followed by worm infestation and dysentery. It is interesting to note the return of malaria to an area where it was eradicated in the late $1950 \mathrm{~s}$. According to health officials in the area, malaria accounts for the majority of fever cases in the valley bottom of the watershed during monsoon.

Domestic water availability has increased over the last 5 and 25 years according to interviewed households (see Figure 3). This is mainly attributable to the various programs on water supply funded by nongovernmental organizations, international nongovernmental organizations, and the government. However, overall availability is still perceived to be limited.

In summary, it can be stated that domestic water shortage during the dry season and microbiological contamination are the main concerns in public water supply. People mainly depend on natural springs, piped springs, and springs collected in spring boxes. Developmental efforts, therefore, have to mainly address these methods or introduce new ways of water supply, supporting but not replacing existing methods.

\section{Conclusions}

Natural water availability in an area is dictated by climatological parameters; the amount of rainfall is limited. Water availability for human use depends on the management of naturally available water. As shown in the example of the 2 Middle Mountain watersheds in Nepal, water resources are becoming increasingly scarce. The shortage of water for agricultural and domestic purposes during the dry months of the year is of particular concern. People perceive that the water supply for agricultural production is decreasing. The main reason for this is agricultural intensification that followed developmental efforts targeted at increasing marketable agricultural and horticultural produce. In this context, the geographical and infrastructural proximity of the watersheds to Kathmandu plays an important role.

Increasingly, water quality issues are becoming a concern for local residents in the area, mainly in the vicinity of settlements. Microbiological data show that fecal contamination is a problem in most water sources. Intensive agriculture is adding to the quality concerns, and mainly, shallow groundwater wells and surface water courses are contaminated and have elevated levels of nitrate and phosphate that often exceed health standards.

With the increasing pressure on available water resources, new forms of water resources management at watershed scale have to be introduced. They have to be based on the social background of the area and on the technical possibilities, in terms of both locally available knowledge and scientific information. Without evaluating water balances, it is increasingly difficult to determine the carrying capacity of water, and without knowing the social setting, it is impossible to address water equity issues. Furthermore, participation of households and communities in the development of new and adapted institutional and technical options is a prerequisite. 
A related article in the Development section of this issue, "Potential solutions to water scarcity in the rural watersheds of Nepal's Middle Mountains," by Juerg Merz, Gopal Nakarmi, and Rolf Weingartner, discusses solutions based on the results of this study. Ed.

\section{ACKNOWLEDGMENTS}

The authors would like to acknowledge the financial support of the Swiss Agency for Development and Cooperation, the International Development Research Centre, and ICIMOD for PARDYP. Furthermore, without the support of the PARDYP Nepal team, this article would not have been possible. Roger White, Hans Schreier, Monika Schaffner, and 2 anonymous reviewers provided valuable comments on the manuscript.

\section{AUTHORS}

Juerg Merz and Rolf Weingartner

Hydrology Group, Institute of Geography, University of Berne, Hallerstrasse 12, 3012 Berne, Switzerland.

jmerz@icimod.org.np (J.M.) and wein@giub.unibe.ch (R.W.)

Gopal Nakarmi, Smita K. Shrestha, Pradeep M. Dangol, Madhav P. Dhakal, Bhawani S. Dongol, and Pravakar B. Shah

International Centre for Integrated Mountain Development, PO Box 3226, Kathmandu, Nepal.

pardyp@icimod.org.np

Bed M. Dahal and Subodh Sharma

School of Environmental and Biological Science, Kathmandu University, Kathmandu, Nepal.

\section{REFERENCES}

Cosgrove WJ, Rijsberman FR. 2000. World Water Vision: Making Water Everybody's Business. London: Earthscan Publications.

[DHM] Department of Hydrology and Meteorology. 1996. Water Quality Data of Rivers of Kathmandu Valley 1992-1995. Kathmandu: Sediment and Water Quality Laboratory, Hydrology Division, DHM.

Kraemer RA, Choudury K, Kampa E. 2001. Protecting Water Resources: PolIution Prevention. Thematic Background Paper at the International Conference on Freshwater in Bonn, 3-7 Dec 2001. http://www.water-2001. de/co_doc/Pollution.pdf; accessed on 7 Nov 2002

Kundzewicz ZN, Budhakooncharoen S, Bronsert A, Hoff H, Lettenmaier D, Menzel L, Schulze R. 2001. Floods and Droughts: Coping with Variability and Climate Change. Thematic Background Paper at the International Conference on Freshwater in Bonn, 3-7 Dec 2001. http://www.water-2001. de/co_doc/Floods.pdf; accessed on 7 Nov 2002.

Liniger H, Weingartner $\boldsymbol{R}$, Grosjean M, editors. 1998. Mountains of the World: Water Towers of the 21st Century. Berne, Switzerland: Mountain Agenda.

Merz J, Dangol PM, Dhakal MP. 2000a. Comparison of climatological balances for the Jhikhu Khola and Yarsha Khola watersheds, Nepal. In: Allen R, Schreier H, Brown S, Shah PB, editors. The People and Resource Dynamics Project: The First Three Years (1996-1999). Kathmandu: International Centre for Integrated Mountain Development, pp 169-184.

Merz J, Hofer T, Weingartner R, Dangol PM, Nakarmi G. 2000b. Water and Erosion Studies in an Integrated Watershed Management Project in the Hindu Kush-Himalayas. Proceedings of the International Conference on Inte- grated Water Resources Management for Sustainable Development; 19-21 Dec 2000; New Delhi. Roorkee, India: National Institute of Hydrology, pp 889-899.

Merz J, Nakarmi G, Shrestha S, Shrestha B, Shah PB, Weingartner R. 2002. Water and Erosion Studies of PARDYP Nepal: The Water Demand and Supply Survey [including CD ROM]. Kathmandu: International Centre for Integrated Mountain Development.

Pandey SP, Joshy D. 2000. Fertilizer Consumption and Food Grain Production in Nepal. Kathmandu: Nepal Agricultural Research Council.

Schreier H, Shah PB. 2000. Soil fertility status and dynamics in the Jhikhu Khola and Yarsha Khola watersheds. In: Allen R, Schreier H, Brown S, Shah PB, editors. The People and Resource Dynamics Project: The First Three Years (1996-1999). Kathmandu: International Centre for Integrated Mountain Development, pp 281-290.

Shrestha B, Brown S. 1995. Land use dynamics and intensification. In: Schreier H, Shah PB, Brown S, editors. Challenge in Mountain Resources Management in Nepal: Processes, Trends, and Dynamics in Middle Mountain Watersheds. Kathmandu: International Centre for Integrated Mountain Development, pp 141-154.

VanWestarp S. 2002. Agricultural Intensification, Soil Fertility Dynamics, and Low-Cost Drip Irrigation in the Middle Mountains of Nepal [MSc thesis]. Vancouver, Canada: University of British Columbia.

Viviroli D. 2001. Zur hydrologischen Bedeutung der Gebirge [MSc thesis] Publikationen Gewässerkunde Nr. 265. Berne, Switzerland: Geographical Institute, University of Berne. 